\title{
Influence of Seed Hardening Treatments on Germination and Seedling Behavior of Sugar Beet (Beta vulgaris L.) Varieties under Salinity Stress
}

\author{
T.Y. Rizk, M. R. El-Bially,. M.A. Farag* and M.A. Abd \\ El-hady \\ Agronomy Dept., Faculty of Agric., Ain Shams Univ. and \\ *Sugar Crops Res. Inst., Agric. Res. Center, Cairo, Egypt.
}

\begin{abstract}
T ABORATORY experiments were carried out to study the effect Uof some seed hardening treatments (polyethylene glycol (PEG -6 bar), humic acid $1 \%$, seawater $2000 \mathrm{ppm}$, seawater $2000 \mathrm{ppm}^{\mathrm{R}}$, tap water and untreated seeds as a control) on germination and seedling growth of six sugar beet varieties. These varieties namely Soultan, Kawmira, Ras poly, Tenor, FD9901 and FD9902. Germination and seedling growth traits (germination percentage, germination rate, seedling length $(\mathrm{cm})$, seedling fresh weight $(\mathrm{mg})$ and seedling vigor) were determined. Results showed that all germination traits were significantly affected by the studied mitigation treatments, sugar beet varieties and their interaction. The highest values of germination \%, as an average of all tested varieties were recorded with polyethylene glycol (P.E.G -6 Bar) followed by that of humic acid $1 \%$ and sea water $2000 \mathrm{ppm}^{\mathrm{R}}$. Enhancement percentages in germination and seedling growth traits were greater with all seed priming treatments compared to the control treatment (untreated seeds). The highest mean values of germination rate, seedling length $(\mathrm{cm})$, seedling fresh weight $(\mathrm{mg})$ and seedling vigor were recorded with humic acid treatment, while the lowest values of the above traits were recorded with the control treatment (untreated seeds). Kawmira and Soultan as the highly salt tolerant varieties recorded the highest values in germination and seedling growth traits. On the contrary the varieties FD9901 and FD9902 recorded the lowest values. The highest enhancement effect in germination percentages and seedling vigor were recorded with the two sensitive varieties FD9901 and FD9902 (at P.E.G (-6 bar), humic acid and S.W. 2000 ppm $^{\text {R }}$.). On the contrary the lowest enhancement effect were recorded with the two highly salt tolerant varieties Kawmira and soultan.
\end{abstract}

Keywords: Mitigation treatments, Salinity stress, Germination percentage, Seedling length, Seedling fresh weight, Seedling vigor, PE -6 bar, Humic acid, Sea water .

Sugar beet is among the most salt tolerant crops, but is to be less tolerant during germination and seedling emergence (Kaffka \& Kurt, 2004). Thus seed priming has been studied as a means to enhance seed/seedling salt tolerance. Murray et al. (1993) found that time to $50 \%$ of maximum emergence of sugar beet seedlings 
was significantly less for those primed with $\mathrm{PEG}_{8000}$ than for non primed seeds in only 1 of 3 years. Yari et al. (2010) studied the effect of different seed priming treatments $\left(\mathrm{PEG}_{6000} 10\right.$ and $20 \%, \mathrm{KCl}_{2} 4 \%, \mathrm{KH}_{2} \mathrm{PO}_{4} 0.5$ and $1 \%$ and distilled water as a control), priming durations (12, 24 and $36 \mathrm{hr}$ ) on germination and early growth of two wheat cultivars (Azar-2 and Sardari 101). Maximum seed germination percentage in cv.Azar-2 was observed when the seeds were primed by PEG $20 \%$ for $12 \mathrm{hr}$. Maximum vigor index (VI) of cv. Azar-2 was obtained from seeds primed with $\mathrm{KH}_{2} \mathrm{PO}_{4} 0.5 \%$, while the lowest germination percentage, germination rate and VI were observed in seeds which primed with $\mathrm{KCl} 4 \%$ solution. Germination rate was improved when seeds were soaked in water and PEG 10\%. Ali \& Elbordiny (2009) soaked seeds of wheat (Tritticum aestivum L.) in two concentrations (50 and $100 \mathrm{ppm}$ ) of potassium humate for different periods (12, 24 and $36 \mathrm{hr}$ ). They showed that more than $90 \%$ of seeds were geminated after five days with the application of $100 \mathrm{ppm}$ potassium humate, particularly achieving the hieghest rate when seeds were soaked for $24 \mathrm{hr}$. Germination rate, shoot and root lengthes, shoot and root dry weights and root/shoot ratio of wheat seedlings were significantly increased with soaking in potassium humate solution at $100 \mathrm{ppm}$ for $24 \mathrm{hr}$ as compared to the control treatment. Patil \& Wadje (2010) showed that, maximum seedling vigor (of soybean and black gram) were recorded when seeds were soaked in $1 \%$ potassium humate and after $12 \mathrm{hr}$ of soaking period against the control treatment (untreated seeds). Hussain et al. (2006) found that sunflower seeds hydro-primed and osmo-primed with $\mathrm{NaCl}$ resulted in lower time taken to $50 \%$ emergence and lower mean emergence time and higher final emergence and energy of emergence. Bajehbaj (2009) tested the effect of seed priming with $\mathrm{KNO}_{3}$ on germination traits and seedling growth of four sunflower (Helianthus annuus L.) cultivars. Germination percentage of primed seeds was greater than that of un-primed seeds. Radicle length, seedling height and dry weight derived from primed seeds were higher compared with un-primed seeds. Mohammadi (2009) investigated the effect of $\mathrm{NaCl}$ priming on seed germination and seedling growth of canola under salinity stress. $\mathrm{NaCl}$ priming increased germination percentage; germination rate and seedling dry weight by $25.57,34.67$ and $36.67 \%$, respectively, as compared with the non-primed seeds.

The current work aims to improve the salt tolerance of the studied sugar beet varieties by using different mitigation treatments.

\section{Materials and Methods}

Laboratory experiments were carried out at the Fac. of Agriculture., Ain Shams University at Shoubra El-Kheima, Kalubia Governorate, Egypt. These experiments aimed to investigate the effect of some seed hardening treatments as mitigation techniques to improve the germination percentages and some seedling growth traits of six sugar beet (Beta vulgaris L.) varieties namely, Soultan, Kawmira, Raspoly, Tenor, FD9901 and FD9902. Seeds of these imported varieties were obtained from the Institute of Sugar Crops Research , Agriculture Egypt. J. Agron. 37, No. 1 (2015) 
Research Center (ARC), Ministry of Agriculture, El-Giza, Egypt. These six varieties were selected from among twenty two varieties early investigated according to their rating as salt tolerance to represent highly tolerant varieties (Soultan and Kawmira), moderately tolerant varieties (Raspoly and Tenor) and sensitive varieties (FD9901 and FD9902) as earlyier reported by Abd El-hady et al. (2014). Seeds of these six selected varieties were soaked in the following solutions as mitigation treatments:

1- Tap water for $12 \mathrm{hr}$ and dried aerobically (TW).

2- Diluted seawater at the concentration of $2000 \mathrm{ppm}$ for $12 \mathrm{hr}$ and dried aerobically (SW $2000 \mathrm{ppm}$ ).

3- Diluted seawater at the concentration of $2000 \mathrm{ppm}$ for $12 \mathrm{hr}$ and dried aerobically for $12 \mathrm{hr}$ and soaked again for $12 \mathrm{hr}$ in the same concentration of the diluted seawater and dried aerobically $\left(\mathrm{SW} 2000 \mathrm{ppm}^{\mathrm{R}}\right.$ ).

4- Humic acid at the concentration of $1 \%$ for $12 \mathrm{hr}$ and dried aerobically (HA $1 \%)$.

5- Polyethylene glycol (PEG 6000) at the concentration of -6 bar (10666 ppm) for $12 \mathrm{hr}$ and dried aerobically (P.E.G -6 Bar ).

6- Untreated seeds used as a control treatment (U T).

Seawater used in this work was obtained from Marsa Matruh beach region. The chemical composition of the used seawater are shown in Table 1.

TABLE 1. The chemical content of the used seawater prior to dillution.

\begin{tabular}{|c|c|c|c|c|c|c|c|}
\hline \multirow{2}{*}{$\mathbf{p H}$} & \multirow{2}{*}{$\mathbf{E C ~ d S / m}$} & \multicolumn{4}{|c|}{ Cation (me/L) } & \multicolumn{2}{|c|}{ Anions (me/L) } \\
\cline { 3 - 8 } & & $\mathbf{C a}^{++}$ & $\mathbf{M g}^{++}$ & $\mathbf{N a}^{+}$ & $\mathbf{K}^{+}$ & $\mathbf{H C O}_{\mathbf{3}}{ }^{+}$ & $\mathbf{C l}^{-}$ \\
\hline 7.96 & 54.8 & 21.25 & 116.7 & 434.7 & 16 & 2.59 & 610 \\
\hline
\end{tabular}

The treated seeds were planted in sand culture in standard plastic germination trays (each tray contains 50 seeds) and irrigated with diluted seawater at the concentration of $8000 \mathrm{ppm}$. The trays were arranged in completely randomized design with four replicates of each treatment. Germination traits germination percentage (after 15 days from sowing), germination rate, seedlings fresh weight, seedlings length and seedling vigor were determined at the end of the experiment (after 30 days from sowing). Seedling vigor was calculated using the following equation according to ISTA (1996):

Seedling vigor $=$ Germination percentage $(\%) X$ Seedling length $(\mathrm{cm})$

\section{Statistical analysis}

The obtained data were subjected to the proper statistical analysis of variance by using complete randomized design according to SAS (1995). Duncan's multiple range was used to differentiate between means.

\section{Germination percentage}

\section{Results and Discussion}

Results in Table 2 showed the significant effects of seed hardening treatments, sugar beet varieties and their interaction on germination percentage. 
The highest values of germination $\%$ as an average of all tested varieties were recorded with polyethylene glycol (PEG -6 bar) (90\%) followed by that of humic acid HA $1 \%(87 \%)$ and sea water SW 2000 ppm $^{\mathrm{R}}(87 \%)$ while, the lowest value $(62 \%)$ was recorded with the control treatment (UT). Results also showed that germination percentages were improved by $45 \%, 40 \%$ and $40 \%$ with PEG (-6bar), humic acid (1\%) and sea water at $2000 \mathrm{ppm}^{\mathrm{R}}$, respectively as compared to the control. These results revealed that the seed hardening treatments mitigated the salt stress harmful effects. Humic acid and polyethylene glycol are characterized by relatively higher carbon contents, molecular weight of osmotica and higher aromatic ring condensation than the seawater. Humic acid contains higher amounts of basic amino acids, but relatively lower amounts of acidic amino acids. These results agreed with Yari et al. (2010) who studied the effect of seed priming treatments $\left(\mathrm{PEG}_{6000} 10\right.$ and 20\%) and distilled water as a control, priming duration $\left(12,24\right.$ and $36 \mathrm{hr}$ ) and three temperatures $\left(20,23\right.$ and $\left.28^{\circ} \mathrm{C}\right)$ on germination of two wheat cultivars (Azar-2 and Sardari 101). Maximum seed germination percentage in cv.Azar-2 was observed when the seeds were primed by PEG $20 \%$ for $12 \mathrm{hr}$ and at $20^{\circ} \mathrm{C}$.

TABLE 2 . Effect of seed hardening treatments on germination percentage of studied sugar beet varieties under salinity stress $(8000 \mathrm{ppm})$ after 15 days from sowing.

\begin{tabular}{|c|c|c|c|c|c|c|c|}
\hline \multirow[t]{2}{*}{ Varieties } & \multirow[b]{2}{*}{ UT } & \multicolumn{5}{|c|}{ Seed hardening treatments } & \multirow[t]{2}{*}{ Means } \\
\hline & & TW & $\begin{array}{c}\text { SW } 2000 \\
\text { ppm }\end{array}$ & $\begin{array}{c}\text { SW } 2000 \\
\text { ppm }^{\mathrm{R}}\end{array}$ & $\begin{array}{l}\text { HA } \\
1 \%\end{array}$ & $\begin{array}{l}\text { PEG } \\
-6 \text { Bar }\end{array}$ & \\
\hline Soultan & $90 \mathrm{ab}$ & $\begin{array}{l}89 a b \\
(-1.1)^{*}\end{array}$ & $\begin{array}{l}89 a b \\
(-1.1)^{*}\end{array}$ & $\begin{array}{l}90 \mathrm{ab} \\
(0.0)^{*}\end{array}$ & $\begin{array}{c}92 \mathrm{a} \\
(2.2)^{*}\end{array}$ & $\begin{array}{l}92 \mathrm{a} \\
(2.2)^{*}\end{array}$ & $90 \mathrm{~A}$ \\
\hline Kawmira & $90 \mathrm{ab}$ & $\begin{array}{l}89 a b \\
(-1.1)^{*}\end{array}$ & $\begin{array}{l}90 \mathrm{ab} \\
(0.0)^{*}\end{array}$ & $\begin{array}{c}91 \mathrm{a} \\
(1.1)^{*}\end{array}$ & $\begin{array}{l}92 \mathrm{a} \\
(2.2)^{*}\end{array}$ & $\begin{array}{l}93 \mathrm{a} \\
(3.3)^{*}\end{array}$ & $91 \mathrm{~A}$ \\
\hline Ras poly & $50 \mathrm{~g}$ & $\begin{array}{l}73 \mathrm{de} \\
(46)^{*}\end{array}$ & $\begin{array}{l}75 \mathrm{de} \\
(50)^{*}\end{array}$ & $\begin{array}{l}83 \mathrm{~cd} \\
(66)^{*}\end{array}$ & $\begin{array}{l}83 \mathrm{~cd} \\
(66)^{*}\end{array}$ & $\begin{array}{l}85 \mathrm{bc} \\
(70)^{*}\end{array}$ & $75 \mathrm{C}$ \\
\hline Tenor & $62 \mathrm{f}$ & $\begin{array}{l}75 \mathrm{de} \\
(21)^{*}\end{array}$ & $\begin{array}{l}77 \mathrm{~d} \\
(24)^{*}\end{array}$ & $\begin{array}{l}85 \mathrm{bc} \\
(37)^{*}\end{array}$ & $\begin{array}{l}88 \mathrm{abc} \\
(42)^{*}\end{array}$ & $\begin{array}{l}90 a b \\
(45)^{*}\end{array}$ & $79 \mathrm{~B}$ \\
\hline FD9901 & $36 \mathrm{i}$ & $\begin{array}{l}70 \mathrm{e} \\
(94)^{*}\end{array}$ & $\begin{array}{l}71 \mathrm{e} \\
(97)^{*}\end{array}$ & $\begin{array}{l}83 \mathrm{~cd} \\
(130)^{*}\end{array}$ & $\begin{array}{l}83 \mathrm{~cd} \\
(130)^{*}\end{array}$ & $\begin{array}{l}89 a b \\
(147)^{*}\end{array}$ & $72 \mathrm{E}$ \\
\hline FD9902 & $44 \mathrm{~h}$ & $\begin{array}{l}70 \mathrm{e} \\
(59)^{*}\end{array}$ & $\begin{array}{l}69 \mathrm{e} \\
(57)^{*}\end{array}$ & $\begin{array}{l}89 a b \\
(102)^{*}\end{array}$ & $\begin{array}{l}85 \mathrm{bc} \\
(93)^{*}\end{array}$ & $\begin{array}{l}88 \mathrm{abc} \\
(100)^{*}\end{array}$ & $74 \mathrm{D}$ \\
\hline Means & $62 \mathrm{D}$ & $\begin{array}{l}78 \mathrm{C} \\
(26)^{*}\end{array}$ & $\begin{array}{l}79 \mathrm{C} \\
(27)^{*}\end{array}$ & $\begin{array}{l}87 \mathrm{~B} \\
(40)^{*}\end{array}$ & $\begin{array}{l}87 \mathrm{~B} \\
(40)^{*}\end{array}$ & $\begin{array}{l}90 \mathrm{~A} \\
(45)^{*}\end{array}$ & \\
\hline
\end{tabular}

* Enhancement percentage (\%) compared with control treatment (UT)

The results indicated clearly different responses of the tested varieties to the studied mitigation treatments. Kawmira and Soultan varieties recorded the highest values $(91 \%$ and $90 \%)$ of germination percentages, respectively while, the variety FD9902 recorded the lowest value (72\%) as an average of all tested hardening treatments. Concerning the interaction effect between varieties and seed hardening treatments on germination percentages, results showed that the response of varieties differed greatly according to the tested seed hardening treatments. Germination percentages of Soultan and Kawmira as highly salt

Egypt. J. Agron. 37, No. 1 (2015) 
tolerant varieties were not significantly affected by the investigated seed hardening treatments. On the contrary the germination percentages of the other varieties, i.e, Raspoly and Tenor (as moderately salt tolerant) and FD9901 and FD9902 (as sensitive) were significantly increased to different extents by the seed hardening treatments. The highest increases as well as the highest improvement in germination \% were noticed with the two sensitive varieties particularly with PEG, HA and SW $2000 \mathrm{ppm}^{\mathrm{R}}$ treatments. The highest enhancement $\%$ on germination (147\%) was noticed with FD9901 variety when the seeds were primed by PEG treatment followed by that of humic acid treatment $(130 \%)$.

\section{Germination rate}

Table 3 demonstrates the effects of seed hardening treatments, sugar beet varieties and their interaction on germination rate of sugar beet varieties. Seeds treated with humic acid $1 \%$ and tap water recorded the highest values of germination rate by the same value (0.8) while, the lowest value (0.72) was recorded with the untreated seeds (control). Results also showed that the varieties Kawmira and Tenor recorded the highest values of germination rate by the same value $(0.77)$, while, the variety Raspoly recorded the lowest value $(0.75)$ which was significantly lower than that recorded with Kawmira and Tenor varieties. In respect to the interaction effect between sugar beet varieties and seed hardening treatments, results revealed that the varieties did not behave the same with the tested seed hardening treatments. Raspoly recorded the highest germination rate with humic acid, while varieties Tenor and Soultan recorded the highest germination rate value with tap water treatment. Meanwhile, the lowest values of germination rate were recorded with FD9901 for sea water $2000 \mathrm{ppm}$ and Soultan with the control treatment.

TABLE 3. Germination rate of sugar beet varieties as affected by seed hardening treatments under salinity stress $(8000 \mathrm{ppm})$.

\begin{tabular}{|c|c|c|c|c|c|c|c|}
\hline \multirow[b]{2}{*}{ Varieties } & \multirow[b]{2}{*}{ UT } & \multicolumn{5}{|c|}{ Seed hardening treatments } & \multirow[b]{2}{*}{ Means } \\
\hline & & TW & $\begin{array}{c}\text { SW } 2000 \\
\text { ppm }\end{array}$ & $\begin{array}{c}\text { SW 2000 } \\
\text { ppmR }\end{array}$ & $\begin{array}{l}\text { HA } \\
1 \%\end{array}$ & $\begin{array}{c}\text { PEG } \\
-6 \text { Bar }\end{array}$ & \\
\hline Soultan & $0.68 \mathrm{c}$ & $\begin{array}{l}0.82 \mathrm{a} \\
(21)^{*}\end{array}$ & $\begin{array}{l}0.73 \mathrm{bc} \\
(7.3)^{*}\end{array}$ & $\begin{array}{l}0.78 \mathrm{~b} \\
(15)^{*}\end{array}$ & $\begin{array}{c}0.81 \mathrm{ab} \\
(19)^{*}\end{array}$ & $\begin{array}{l}0.77 \mathrm{~b} \\
(13)^{*}\end{array}$ & $0.76 \mathrm{ab}$ \\
\hline Kawmira & $0.76 \mathrm{~b}$ & $\begin{array}{l}0.80 \mathrm{ab} \\
(5.3)^{*}\end{array}$ & $\begin{array}{l}0.79 \mathrm{~b} \\
(3.9)^{*}\end{array}$ & $\begin{array}{l}0.75 b c \\
(-1.3)^{*}\end{array}$ & $\begin{array}{l}0.78 \mathrm{~b} \\
(2.6)^{*}\end{array}$ & $\begin{array}{l}0.76 \mathrm{~b} \\
(00)^{*}\end{array}$ & $0.77 \mathrm{a}$ \\
\hline Raspoly & $0.70 \mathrm{bc}$ & $\begin{array}{l}0.78 \mathrm{~b} \\
(11)^{*}\end{array}$ & $\begin{array}{l}0.75 \mathrm{bc} \\
(7.1)^{*}\end{array}$ & $\begin{array}{l}0.73 \mathrm{bc} \\
(4.3)^{*}\end{array}$ & $\begin{array}{l}0.83 \mathrm{a} \\
(18)^{*}\end{array}$ & $\begin{array}{l}0.74 \mathrm{bc} \\
(5.7)^{*}\end{array}$ & $0.75 \mathrm{~b}$ \\
\hline Tenor & $0.76 \mathrm{~b}$ & $\begin{array}{l}0.82 \mathrm{a} \\
(7.9)^{*}\end{array}$ & $\begin{array}{l}0.72 b c \\
(-5.3)^{*}\end{array}$ & $\begin{array}{l}0.77 \mathrm{~b} \\
(1.3)^{*}\end{array}$ & $\begin{array}{l}0.81 \mathrm{ab} \\
(6.6)^{*}\end{array}$ & $\begin{array}{l}0.76 \mathrm{~b} \\
(00)^{*}\end{array}$ & $0.77 \mathrm{a}$ \\
\hline FD9901 & $0.73 \mathrm{bc}$ & $\begin{array}{c}0.81 \mathrm{ab} \\
(11)^{*}\end{array}$ & $\begin{array}{l}0.69 \mathrm{c} \\
(-5.5)^{*}\end{array}$ & $\begin{array}{l}0.76 \mathrm{~b} \\
(4.1)^{*}\end{array}$ & $\begin{array}{l}0.77 \mathrm{~b} \\
(5.5)^{*}\end{array}$ & $\begin{array}{l}0.78 \mathrm{~b} \\
(6.8)^{*}\end{array}$ & $0.76 \mathrm{ab}$ \\
\hline FD9902 & $0.72 \mathrm{bc}$ & $\begin{array}{l}0.76 \mathrm{~b} \\
(5.5)^{*}\end{array}$ & $\begin{array}{l}0.70 \mathrm{bc} \\
(-2.8)^{*}\end{array}$ & $\begin{array}{c}0.80 \mathrm{ab} \\
(11)^{*}\end{array}$ & $\begin{array}{c}0.80 \mathrm{ab} \\
(11)^{*}\end{array}$ & $\begin{array}{l}0.77 \mathrm{~b} \\
(6.9)^{*}\end{array}$ & $0.76 \mathrm{ab}$ \\
\hline Means & $0.72 \mathrm{c}$ & $\begin{array}{l}0.80 \mathrm{a} \\
(11)^{*}\end{array}$ & $\begin{array}{l}0.73 \mathrm{bc} \\
(1.4)^{*}\end{array}$ & $\begin{array}{l}0.76 \mathrm{~b} \\
(5.5)^{*}\end{array}$ & $\begin{array}{l}0.80 \mathrm{a} \\
(11)^{*}\end{array}$ & $\begin{array}{l}0.76 \mathrm{~b} \\
(5.5)^{*}\end{array}$ & \\
\hline
\end{tabular}

Enhancement percentage (\%) compared with control treatment (UT) . 
Similar findings were early reported by Mohammdi (2009) on canola seeds and Bajehbaj (2009) on sunflower. They showed that germination rates of primed seeds were greater than that of non-primed seeds. Moreover, Hussain et al (2006) found that sunflower seeds primed with $\mathrm{NaCl}$ resulted in lower time taken to $50 \%$ emergence and main emergence time and higher final emergence. Ali \& Elbordiny (2009) found that germination rate of wheat seeds were significantly increased with soaking in potassium humate solution at $100 \mathrm{ppm}$ for $24 \mathrm{hr}$ as compared to the control (soaking in distilled water).

\section{Seedling length}

Table 4 shows that seedling length of the studied sugar beet varieties were significantly affected to different extents by seed hardening treatments, sugar beet varieties and their interaction. Seeds treated with humic acid $1 \%$ recorded the highest values in seedling length. However, the lowest values were obtained with seawater 2000 ppm and the control treatment (untreated seeds). Results also showed that the seedling length of Soultan and Kawmira varieties were significantly superior when compared with other varieties. Concerning the interaction effect between seed hardening treatments and sugar beet varieties, results revealed that the highest and the lowest values in seedling length $(10.4$ and $4.9 \mathrm{~cm})$ were recorded with Kawmira treated with humic acid $1 \%$ and with Raspoly treated with the control treatment, respectively. These results revealed clearly that the tested varieties did not response similarly to the seed hardening treatments. It is worth to mention here that the greatest enhancement in seedling length $(96 \%)$ was recorded with Kawmira variety treated with humic acid (1\%). These results are in general agreement with those of Ali \& Elbordiny (2009) who found that shoot and root lengthes of wheat seedlings were significantly increased with soaking seeds in potassium humate solution particularly with 50 and $100 \mathrm{ppm}$ concentrations for $24 \mathrm{hr}$ compared to the same period of soaking in distilled water. Bajehbaj (2009) reported that shoot and root lengthes of sunflower seedling were increased significantly with osmopriming treatment compared to un-primed seeds under salinity stress conditions.

\section{Seedling fresh weight ( $\mathrm{mg}$ )}

Effect of seed hardening treatments, sugar beet varieties and their interaction on seedling fresh weight are shown in Table 5. Data showed that seeds soaked in tap water and humic acid $1 \%$ recorded the highest mean values of seedling fresh weights by 67 and $65.9 \mathrm{mg}$, respectively. On the other hand, the control treatment (untreated) gave the lowest mean value $(39.2 \mathrm{mg})$. The results also showed that the variety Soultan was significantly superior in seedling fresh weight as compared to the other varieties while, the variety FD9902 recorded the lowest mean value. In respect of the interaction effect between seed hardening treatments and sugar beet varieties the highest values were recorded by humic acid $1 \%$ treatment with the varieties Raspoly, Soultan and Tenor, while the lowest value was recorded by the control treatment (untreated) with the variety FD9901. Ali \& Elbordiny (2009) confirmed that soaking wheat seeds in potassium humate solution at $100 \mathrm{ppm}$ for $24 \mathrm{hr}$ significantly increased shoot and root dry weights and root/shoot ratio of wheat seedlings as compared to the control (soaking in distilled water). Mohammadi (2009) reported that canola seeds primed with $\mathrm{NaCl}$ increased seedling dry weight by $36.67 \%$ as compared with the non-primed seeds.

Egypt. J. Agron. 37, No. 1 (2015) 
TABLE 4. Seedling length $(\mathrm{cm})$ of sugar beet varieties as affected by seed hardening treatments under salinity stress $(\mathbf{8 0 0 0} \mathrm{ppm})$ (after 30 days from sowing).

\begin{tabular}{|c|c|c|c|c|c|c|c|}
\hline \multirow[t]{2}{*}{ Varieties } & \multirow[t]{2}{*}{ UT } & \multicolumn{5}{|c|}{ Seed hardening treatments } & \multirow[t]{2}{*}{ Means } \\
\hline & & TW & $\begin{array}{c}\text { SW } 2000 \\
\text { ppm }\end{array}$ & $\begin{array}{c}\text { SW 2000 } \\
\text { ppm }^{\mathrm{R}}\end{array}$ & $\begin{array}{l}\text { HA } \\
1 \%\end{array}$ & $\begin{array}{l}\text { PEG } \\
-6 \text { Bar }\end{array}$ & \\
\hline Soultan & $6.7 \mathrm{~d}$ & $\begin{array}{l}8.8 \mathrm{ab} \\
(31)^{*}\end{array}$ & $\begin{array}{l}7.4 \mathrm{c} \\
(10)^{*}\end{array}$ & $\begin{array}{c}7.8 \mathrm{bc} \\
(16)^{*}\end{array}$ & $\begin{array}{l}9.8 \mathrm{ab} \\
(46)^{*}\end{array}$ & $\begin{array}{l}8.9 \mathrm{ab} \\
(33)^{*}\end{array}$ & $8.2 \mathrm{~A}$ \\
\hline Kawmira & $5.3 \mathrm{ef}$ & $\begin{array}{l}9.8 \mathrm{ab} \\
(85)^{*}\end{array}$ & $\begin{array}{l}6.6 \mathrm{~d} \\
(25)^{*}\end{array}$ & $\begin{array}{l}7.2 \mathrm{~cd} \\
(36)^{*}\end{array}$ & $\begin{array}{l}10.4 \mathrm{a} \\
(96)^{*}\end{array}$ & $\begin{array}{l}8.0 \mathrm{bc} \\
(51)^{*}\end{array}$ & $7.9 \mathrm{AB}$ \\
\hline Ras poly & $4.9 \mathrm{f}$ & $\begin{array}{l}8.0 \mathrm{bc} \\
(\pi r)^{*}\end{array}$ & $\begin{array}{l}5.6 \mathrm{e} \\
(46)^{*}\end{array}$ & $\begin{array}{l}6.5 \mathrm{~d} \\
(1 \varepsilon)^{*}\end{array}$ & $\begin{array}{l}8.2 \mathrm{bc} \\
(\mathrm{TV})^{*}\end{array}$ & $\begin{array}{l}7.1 \mathrm{~cd} \\
(\varepsilon 0)^{*}\end{array}$ & $6.7 \mathrm{~B}$ \\
\hline Tenor & $5.2 \mathrm{ef}$ & $\begin{array}{l}8.4 \mathrm{~b} \\
(\pi)^{*}\end{array}$ & $\begin{array}{l}5.9 \mathrm{de} \\
(\mathrm{Ir})^{*}\end{array}$ & $\begin{array}{l}6.1 \mathrm{de} \\
(r r)^{*}\end{array}$ & $\begin{array}{l}8.1 \mathrm{bc} \\
(07)^{*}\end{array}$ & $\begin{array}{l}6.7 \mathrm{~d} \\
(\mathrm{rq})^{*}\end{array}$ & $6.7 \mathrm{~B}$ \\
\hline FD9901 & $5.8 \mathrm{de}$ & $\begin{array}{l}7.7 \mathrm{c} \\
(r r)^{*}\end{array}$ & $\begin{array}{l}5.8 \mathrm{de} \\
(. .)^{*}\end{array}$ & $\begin{array}{l}6.6 \mathrm{~d} \\
(1 \xi)^{*}\end{array}$ & $\begin{array}{l}7.2 \mathrm{~cd} \\
(r \varepsilon)^{*}\end{array}$ & $\begin{array}{l}7.7 \mathrm{c} \\
(\mathrm{rr})^{*}\end{array}$ & $6.8 \mathrm{~B}$ \\
\hline FD9902 & $5.5 \mathrm{ef}$ & $\begin{array}{l}7.8 \mathrm{bc} \\
(\varepsilon r)^{*}\end{array}$ & $\begin{array}{l}5.3 \text { ef } \\
(-3.6)^{*}\end{array}$ & $\begin{array}{l}6.0 \mathrm{de} \\
(9.1)^{*}\end{array}$ & $\begin{array}{l}8.1 \mathrm{bc} \\
(47)^{*}\end{array}$ & $\begin{array}{l}8.3 \mathrm{bc} \\
(51)^{*}\end{array}$ & $6.8 \mathrm{~B}$ \\
\hline Means & $6.6 \mathrm{~B}$ & $\begin{array}{l}8.4 \mathrm{~A} \\
(27)^{*}\end{array}$ & $\begin{array}{l}6.1 \mathrm{~B} \\
(-6.1)^{*}\end{array}$ & $\begin{array}{l}6.7 \mathrm{~B} \\
(1.5)^{*}\end{array}$ & $\begin{array}{l}8.5 \mathrm{~A} \\
(29)^{*}\end{array}$ & $\begin{array}{c}7.8 \mathrm{AB} \\
(18)^{*}\end{array}$ & \\
\hline
\end{tabular}

* Enhancement percentage (\%) compared with control treatment (UT) .

TABLE 5. Seedling fresh weight (mg) of sugar beet varieties as affected by seed hardening treatments under salinity stress $(8000 \mathrm{ppm})$ after 30 days from sawing.

\begin{tabular}{|c|c|c|c|c|c|c|c|}
\hline \multirow[t]{2}{*}{ Varieties } & \multirow[t]{2}{*}{$\overline{\mathbf{U T}}$} & \multicolumn{5}{|c|}{ Seed hardening treatments } & \multirow[t]{2}{*}{ Means } \\
\hline & & T.W & $\begin{array}{l}\text { S.W } \\
2000 \\
\text { ppm }\end{array}$ & $\begin{array}{c}\text { S.W } \\
2000 \\
\text { ppm }^{R}\end{array}$ & $\begin{array}{l}\text { H.A } \\
1 \%\end{array}$ & $\begin{array}{l}\text { P.E.G } \\
\text {-6 Bar }\end{array}$ & \\
\hline Soultan & $50.9 \mathrm{fg}$ & $\begin{array}{c}69.0 \mathrm{~b} \\
(35)^{*}\end{array}$ & $\begin{array}{c}52.2 \mathrm{ef} \\
(2.5)^{*}\end{array}$ & $\begin{array}{l}51.7 \mathrm{f} \\
(1.6)^{*}\end{array}$ & $\begin{array}{c}71.2 \mathrm{ab} \\
(40)^{*}\end{array}$ & $\begin{array}{c}61.5 \mathrm{~cd} \\
(21)^{*}\end{array}$ & $59.4 \mathrm{a}$ \\
\hline Kawmira & $48.8 \mathrm{~g}$ & $\begin{array}{c}71.0 \mathrm{ab} \\
(45)^{*}\end{array}$ & $\begin{array}{c}47.5 \mathrm{gh} \\
(-1.4)^{*}\end{array}$ & $\begin{array}{c}51.2 \mathrm{fg} \\
(4.9)^{*}\end{array}$ & $\begin{array}{l}63.0 \mathrm{c} \\
(29)^{*}\end{array}$ & $\begin{array}{l}58.8 \mathrm{~d} \\
(20)^{*}\end{array}$ & $56.7 \mathrm{~b}$ \\
\hline Raspoly & $33.3 \mathrm{k}$ & $\begin{array}{l}68.0 \mathrm{~b} \\
(102)^{*}\end{array}$ & $\begin{array}{l}41.2 \mathrm{ij} \\
(24)^{*}\end{array}$ & $\begin{array}{l}41.8 \mathrm{i} \\
(25)^{*}\end{array}$ & $\begin{array}{l}73.0 \mathrm{a} \\
(119)^{*}\end{array}$ & $\begin{array}{l}47.7 \mathrm{~g} \\
(43)^{*}\end{array}$ & $50.8 \mathrm{c}$ \\
\hline Tenor & $39.4 \mathrm{j}$ & $\begin{array}{c}70.5 \mathrm{~b} \\
(79)^{*}\end{array}$ & $\begin{array}{l}41.7 \mathrm{i} \\
(5.8)^{*}\end{array}$ & $\begin{array}{l}43.3 \mathrm{~h} \\
(9.9)^{*}\end{array}$ & $\begin{array}{c}71.1 \mathrm{ab} \\
(80)^{*}\end{array}$ & $\begin{array}{c}60.1 \mathrm{~d} \\
(52)^{*}\end{array}$ & $54.4 \mathrm{~b}$ \\
\hline FD9901 & $29.0 \mathrm{~h}$ & $\begin{array}{l}61.4 \mathrm{~cd} \\
(111)^{*}\end{array}$ & $\begin{array}{l}41.4 \mathrm{ij} \\
(43)^{*}\end{array}$ & $\begin{array}{c}43.0 \mathrm{~h} \\
(48)^{*}\end{array}$ & $\begin{array}{l}63.0 \mathrm{c} \\
(117)^{*}\end{array}$ & $\begin{array}{l}61.4 \mathrm{~cd} \\
(111)^{*}\end{array}$ & $49.9 \mathrm{~cd}$ \\
\hline FD9902 & $34.0 \mathrm{k}$ & $\begin{array}{c}62.1 \mathrm{~cd} \\
(83)^{*}\end{array}$ & $\begin{array}{c}41.1 \mathrm{ij} \\
(21)^{*}\end{array}$ & $\begin{array}{l}45.5 \mathrm{~h} \\
(34)^{*}\end{array}$ & $\begin{array}{l}54.0 \mathrm{e} \\
(59)^{*}\end{array}$ & $\begin{array}{c}51.6 \mathrm{fg} \\
(52)^{*}\end{array}$ & $48.1 \mathrm{~d}$ \\
\hline Means & $39.2 \mathrm{~d}$ & $\begin{array}{c}67.0 \mathrm{a} \\
(71)^{*}\end{array}$ & $\begin{array}{l}44.2 \mathrm{c} \\
(13)^{*}\end{array}$ & $\begin{array}{l}46.2 \mathrm{c} \\
(18)^{*}\end{array}$ & $\begin{array}{c}65.9 \mathrm{a} \\
(68)^{*}\end{array}$ & $\begin{array}{c}56.9 \mathrm{~b} \\
(45)^{*}\end{array}$ & \\
\hline
\end{tabular}

* Enhancement percentage (\%) compared with control treatment (UT) . 
Seedling vigor

Results in Table 6 shows the significant effects of seed hardening treatments, sugar beet varieties and their interaction on seedling vigor. The highest mean values of seedling vigor as an average of all tested varieties were recorded with humic acid 1\% (754) followed by that of PEG (-6 bar) (698) and tap water (659) while, the lowest mean value (310) was recorded with the control (untreated seeds) treatment. These results indicated clearly that the seed hardening treatments mitigated to different extents the detrimental effect of salt stress on seedling vigor. Results also revealed that seedling vigor as an average over all varieties were enhanced by $143 \%, 125 \%$ and $112 \%$ with humic acid (1\%), PEG (-6bar) and tap water, respectively as compared to the control (untreated treatments). Results also showed that the variety Soultan recorded the highest mean value (744) in seedling vigor as an average of all seed hardening treatments followed by the variety Kawmira (714). On the other hand, the variety FD9901 recorded the lowest mean value (499).

TABLE 6. Seedling vigor of sugar beet varieties as affected by seed hardening treatments under salinity stress $(\mathbf{8 0 0 0} \mathbf{~ p p m})$ after 30 days from sawing.

\begin{tabular}{|c|c|c|c|c|c|c|c|}
\hline \multirow[t]{2}{*}{ Varieties } & \multirow[t]{2}{*}{ UT } & \multicolumn{5}{|c|}{ Seed hardening treatments } & \multirow[t]{2}{*}{ Means } \\
\hline & & TW & $\begin{array}{c}\text { SW } 2000 \\
\text { ppm }\end{array}$ & $\begin{array}{c}\text { SW } 2000 \\
\text { ppm }^{\mathrm{R}}\end{array}$ & $\begin{array}{l}\text { HA } \\
1 \%\end{array}$ & $\begin{array}{l}\text { PEG } \\
-6 \text { Bar }\end{array}$ & \\
\hline Soultan & $603 \mathrm{gh}$ & $\begin{array}{l}781 \mathrm{c} \\
(29)^{*}\end{array}$ & $\begin{array}{l}659 \mathrm{f} \\
(9.3)^{*}\end{array}$ & $\begin{array}{c}702 \text { def } \\
(16)^{*}\end{array}$ & $\begin{array}{l}902 \mathrm{ab} \\
(49)^{*}\end{array}$ & $\begin{array}{l}819 \mathrm{c} \\
(36)^{*}\end{array}$ & $744 \mathrm{~A}$ \\
\hline Kawmira & $478 \mathrm{j}$ & $\begin{array}{l}873 \mathrm{~b} \\
(82)^{*}\end{array}$ & $\begin{array}{l}594 \text { gh } \\
(24)^{*}\end{array}$ & $\begin{array}{l}656 \mathrm{ff} \\
(37)^{*}\end{array}$ & $\begin{array}{l}939 \mathrm{a} \\
(96)^{*}\end{array}$ & $\begin{array}{l}744 \mathrm{~d} \\
(55)^{*}\end{array}$ & $714 \mathrm{~B}$ \\
\hline Raspoly & $246 \mathrm{~m}$ & $\begin{array}{l}584 \mathrm{~h} \\
(137)^{*}\end{array}$ & $\begin{array}{l}420 \mathrm{k} \\
(71)^{*}\end{array}$ & $\begin{array}{c}540 \mathrm{i} \\
(119)^{*}\end{array}$ & $\begin{array}{l}681 \text { ef } \\
(177)^{*}\end{array}$ & $\begin{array}{l}604 \mathrm{gh} \\
(145)^{*}\end{array}$ & $513 \mathrm{DE}$ \\
\hline Tenor & $323 \mathrm{~L}$ & $\begin{array}{l}631 \mathrm{f} \\
(95)^{*}\end{array}$ & $\begin{array}{l}455 \mathrm{jk} \\
(41)^{*}\end{array}$ & $\begin{array}{l}519 \mathrm{ij} \\
(61)^{*}\end{array}$ & $\begin{array}{l}713 \mathrm{de} \\
(121)^{*}\end{array}$ & $\begin{array}{l}603 \mathrm{gh} \\
(86)^{*}\end{array}$ & $541 \mathrm{C}$ \\
\hline FD9901 & $209 \mathrm{~m}$ & $\begin{array}{l}539 \mathrm{i} \\
(158)^{*}\end{array}$ & $\begin{array}{l}412 \mathrm{k} \\
(97)^{*}\end{array}$ & $\begin{array}{l}548 \mathrm{hi} \\
(162)^{*}\end{array}$ & $\begin{array}{l}598 \mathrm{gh} \\
(186)^{*}\end{array}$ & $\begin{array}{l}686 \mathrm{ef} \\
(228)^{*}\end{array}$ & $499 \mathrm{E}$ \\
\hline FD9902 & $242 \mathrm{~m}$ & $\begin{array}{c}546 \mathrm{i} \\
(125)^{*}\end{array}$ & $\begin{array}{l}366 \mathrm{~L} \\
(51)^{*}\end{array}$ & $\begin{array}{l}534 \mathrm{i} \\
(120)^{*}\end{array}$ & $\begin{array}{l}689 \text { ef } \\
(185)^{*}\end{array}$ & $\begin{array}{l}731 d \\
(202)^{*}\end{array}$ & $518 \mathrm{D}$ \\
\hline Means & $310 \mathrm{E}$ & $\begin{array}{l}659 \mathrm{~B} \\
(112)^{*}\end{array}$ & $\begin{array}{l}485 \mathrm{D} \\
(56)^{*}\end{array}$ & $\begin{array}{l}583 \mathrm{C} \\
(88)^{*}\end{array}$ & $\begin{array}{l}754 \mathrm{~A} \\
(143)^{*}\end{array}$ & $\begin{array}{l}\text { 698 B } \\
(125)^{*}\end{array}$ & \\
\hline
\end{tabular}

*Enhancement percentage (\%) compared with the control treatment (UT)

The interaction between sugar beet varieties and seed hardening treatments on seedling vigor, showed that the response of varieties differed significantly according to seed hardening treatments. Seedling vigor of the varieties FD9901 and FD9902 recorded the highest values of seedling vigor with the PEG (-6 bar) treatment while, other varieties, i.e. Soultan, Kawmira, Raspoly and Tenor recorded the highest values with humic acid treatment. These results are in agreement with those of Fu et al. (1988) who studied the osmo-conditioning of peanut seeds with $20-25 \%$ PEG for $48 \mathrm{hr}$ which offered an effective means for raising germination percentage and vigor index in various deteriorated peanut seeds. Patil \& Wadje (2010) showed that, maximum seedling vigor of soybean

Egypt. J. Agron. 37, No. 1 (2015) 
and black gram were recorded in $1.0 \%$ potassium humate and after $12 \mathrm{hr}$ soaking period in soybean and black gram against the control treatment.

\section{References}

Ali, Laila K.M. and Elbordiny, M.M. (2009) Response of wheat plants to potassium humate application. J. Appl. Sci. Res. 5(9), 1202-1209.

Abd El-hady, M.A., Rizk, T.Y., El-Bially, M.E. and Farag, M.A. (2014) Salt tolerance index of twenty two sugar beet (Beta vulgaris L.) varieties at early stages. Arab Univ. J. Agric. Sci. 22(2), 361- 369.

Bajehbaj, A. A. (2009) The effects of $\mathrm{NaCl}$ priming on salt tolerance in sunflower germination and seedling grown under salinity conditions. Afr. J. Biotechnol. 9(2), 1764-1770

Fu, J.R., Lu, S.H., Chen, R.Z., Zhang, B.Z., Liu, Z.S., Li, Z.S. and Cal, D.Y. (1988) Osmoconditioning of peanut ( Arachis hypogea L.) seeds with PEG to improve vigor and some biochemical activities. Seed Sci. Technol. 16, 197-212.

Hussain, M., Farouq, M., Shahzad, M., Basra, A. and Ahmed, N. (2006) Influence of seed priming techniques on the seedling establishment, yield and quality of hybrid sunflower. Int. J. Agric. Biol. 8(1), 14-18.

ISTA (1996) International Rules for Seed Testing. Seed Sci. \& Technol. 24, Supplement.

Kaffka, S. and Kurt, H. (2004) The effects of saline soil, irrigation, and seed treatments on sugar beet. J. Sugar Beet Res. 41 (3), 61-72.

Mohammadi, G.R. (2009) The influence of $\mathrm{NaCl}$ priming on seed germination and seedling growth of canola (Brassica napus L.) under salinity conditions. J. Agric. \& Environ. Sci. 5(5), 696-700.

Murray, A.G., Swensen, J.B. and Gallian, J.J. (1993) Emergence of sugar beet seedling at low soil temperature following seed soaking and priming. Hot. Sci. 28(1), $31-32$.

Patil, R. and Wdje, S. (2010) Effect of various concentrations of potassium humate (0.1 to $1 \%$ ) soaking periods ( 3 to $24 \mathrm{hr}$ ) on seedling vigour of soybean and black gram. Arch. Appl. Sci. Res. 2(2),190-193.

SAS (1995) "Statistical Analysis System". $6^{\text {th }}$ ed., Institute Inc., Gary., NC., USA.

Yari, L., Aghaalikani, M. and Khazaei, F. (2010) Effect of seed priming duration and temperature on seed germination behavior bread wheat (Triticum aestivum L). J. Agric. Biol. Sci. 5(1),1-6.

(Received $1 / 2 / 2015$

accepted $15 / 4 / 2015)$ 


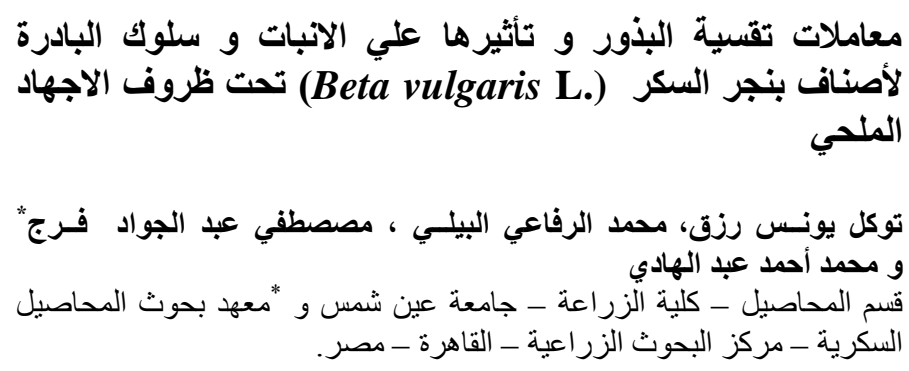

أقيمت تجربة إنبات لدر اسة تأثثر بعض معاملات تقسية البذور عن طريق النقع في (البي

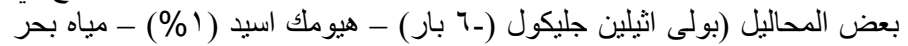

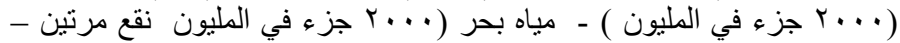

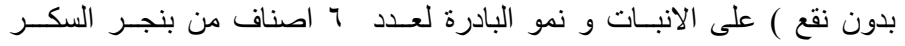

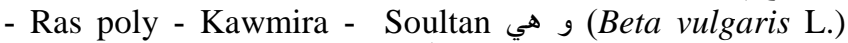
، تم أخذ قرءات النسبة المئوية للإنبات (FD9902 - FD9901-Tenor

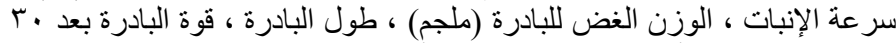

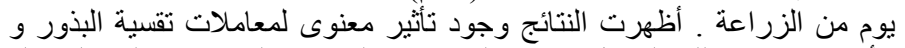

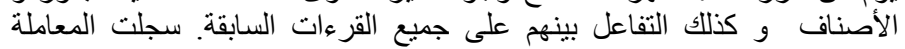

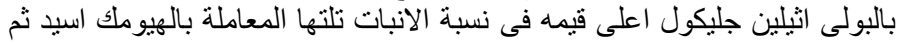

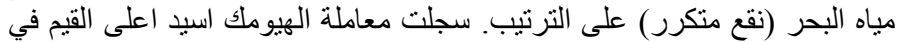

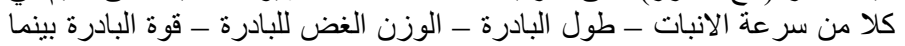

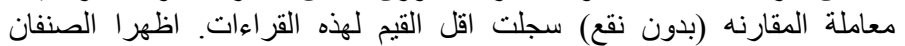
Soultan - Kawmira

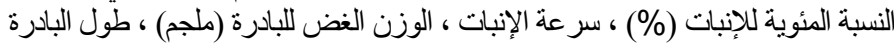

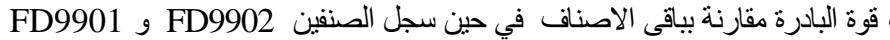

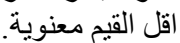

